\title{
Ingested soluble CD14 from milk is transferred intact into the blood of newborn rats
}

\author{
Tonya L. Ward', William J. Spencer', Laura D.R. Davis', JoAnn Harrold ${ }^{2,3}$, David R. Mack ${ }^{1-3}$ and Illimar Altosaar'
}

BACKGROUND: Milk acts as an edible immune system that is transferred from mother to newborn. Soluble Cluster of Differentiation 14 (sCD14) is a protein found in significant quantities in human milk $(\sim 8-29 \mu \mathrm{g} / \mathrm{ml})$. At a 10 -fold lower concentration in the blood $(\sim 3 \mu \mathrm{g} / \mathrm{ml})$, the most notable role of sCD14 is to sequester lipopolysaccharides of Gram-negative bacteria from immune cells.

METHODS: To explore the pharmacodynamics of this milk protein and its biological fate, the biodistribution of radiolabeled sCD14 $\left({ }^{14} \mathrm{C},{ }^{125}\right)$ ) was monitored in 10 -d-old rat pups.

RESULTS: Up to $3.4 \pm 2.2 \%$ of the radiolabeled sCD14 administered was observed, intact, in the pup blood for up to $8 \mathrm{~h}$ post-ingestion. Additionally, $30.3 \pm 13.0 \%$ of the radiolabeled sCD14 administered was observed degraded in the stomach at $8 \mathrm{~h}$ post-ingestion. A reservoir of intact, administered SCD14 $(3.2 \pm 0.3 \%)$, however, remained in the stomach at $8 \mathrm{~h}$ postingestion. Intact sCD14 was observed in the small intestine at $5.5 \pm 1.6 \%$ of the dose fed at $8 \mathrm{~h}$ post-ingestion.

CONCLUSION: The presence of intact sCD14 in the blood and the gastrointestinal tract of newborns post-ingestion has implications in the development of allergies, obesity, and other inflammation-related pathogeneses later in life.

-luster of Differentiation 14 (CD14) is a 48-kDa pattern recognition receptor first discovered as a sensor for the lipopolysaccharides (LPS) of Gram-negative bacteria. CD14 exists either as a glycosyl phosphatidylinositol-anchored membrane protein (mCD14) on the cell surface or as a soluble protein (sCD14) found in bodily fluids. Soluble CD14 is observed in the blood at a concentration of $3.71 \pm 0.59 \mu \mathrm{g} / \mathrm{ml}$ and at a onefold higher concentration in human milk, $20.10 \pm 8.74 \mu \mathrm{g} /$ $\mathrm{ml}$ (at $5 \mathrm{~d}$ postpartum) to $12.16 \pm 3.75 \mu \mathrm{g} / \mathrm{ml}$ (at 3 mo postpartum) $(1,2)$. The two forms of CD14 (membrane-bound or soluble) appear functionally interchangeable because they both can enhance proinflammatory signaling in response to LPS through Toll-like receptor 4 (TLR4), alerting the immune system of potential infections (3).

In blood, circulating sCD14 decreases LPS-related mortality and septic shock, presumably by sequestering LPS from mCD14/TLR4-expressing immune cells (4). This allows clearance of LPS from the body before activation of the immune system. Recent studies have also implicated sCD14 in inflammation-related diseases. For example, both circulating and milk-derived sCD14 levels have been correlated with fat mass in humans, and the genomic elimination of the CD14 gene in mice attenuated symptoms of obesity, such as hypertension (5-7). Furthermore, CD14 is thought to influence the type of bacteria colonizing the gastrointestinal (GI) tract of infants (8). Therefore, similar to many other immunologically relevant agents present in human milk, such as serum proteins, cytokines, and immunoglobulins milk-derived sCD14 may play a role in inflammation, development, and overall infant health, as discussed in a recent review (9).

The high concentration of sCD14 in human milk exposes a breastfeeding infant to milligram quantities of the protein per day. In our initial study, however, neither intact nor degraded portions of sCD14 are found in the feces of breastfed infants (10). Immunoprecipitation of sCD14 from milk and in vitro digests demonstrates that $\mathrm{sCD} 14$ is able to complex with other milk proteins, namely, $\alpha$-lactalbumin, which protect it from degradation (11). Taken together, the combined proteolytic protection of sCD14 by milk components and lack of sCD14 in infant feces raise the possibility that $\mathrm{sCD} 14$ may be absorbed intact along the GI tract of the infant, as we earlier suggested (10).

Whole-protein uptake across the epithelium and into the blood stream has been previously described for other milk proteins such as immunoglobulins (12). Once translocated to the blood, these milk proteins contribute to the infant's endogenous serum pool of proteins, stimulating the immune system and offering passive immunity (for review, see ref. 13). Because sCD14 levels continue to increase during the first 18 mo of life, sCD14 provided by the mother via her milk may afford additional surveillance against bacteria in the GI tract or blood of the infant (8).

In healthy full-term infants, "gut closure" (a decrease in intestinal permeability with age) occurs within a few days postpartum, which can be altered depending on the nutrient source (such as human milk vs. formula (14). In rodents, gut closure is further delayed and correlates with the weaning age of 17-21 d postpartum (15). In this study, 10-d-old rat pups

\footnotetext{
'Department of Biochemistry, Microbiology and Immunology, University of Ottawa, Ottawa, Ontario, Canada; ${ }^{2}$ Department of Pediatrics, University of Ottawa, Ottawa, Ontario, Canada; ${ }^{3}$ Neonatal Intensive Care Unit, Gastroenterology, Department of Pediatrics, Children's Hospital of Eastern Ontario, Ottawa, Ontario, Canada. Correspondence:

Illimar Altosaar (altosaar@uottawa.ca) 
were used as a model for newborn human infants in whom gut closure has not yet occurred (term infants: $1-3 \mathrm{~d}$ old; or preterm infants: 1-10 d old). This age was chosen because it correlates with the greatest expression of sCD14 in human milk, which can reach concentrations as high as $67.09 \pm 27.61 \mu \mathrm{g} /$ $\mathrm{ml}$ in colostrum $(1,2)$. Using radiolabeled proteins as a means to track digestive fate, we address the hypothesis that sCD14 remains intact along the digestive tract and is absorbed intact into the circulatory system, post-ingestion.

\section{RESULTS}

\section{Ingested SCD14 Persists in the GI Tract}

Within the stomach, $3.2 \pm 0.3 \%$ of the $\left[{ }^{14} \mathrm{C}\right]-\mathrm{CD} 14$ dose fed remained intact at $8 \mathrm{~h}$ post-ingestion, which did not
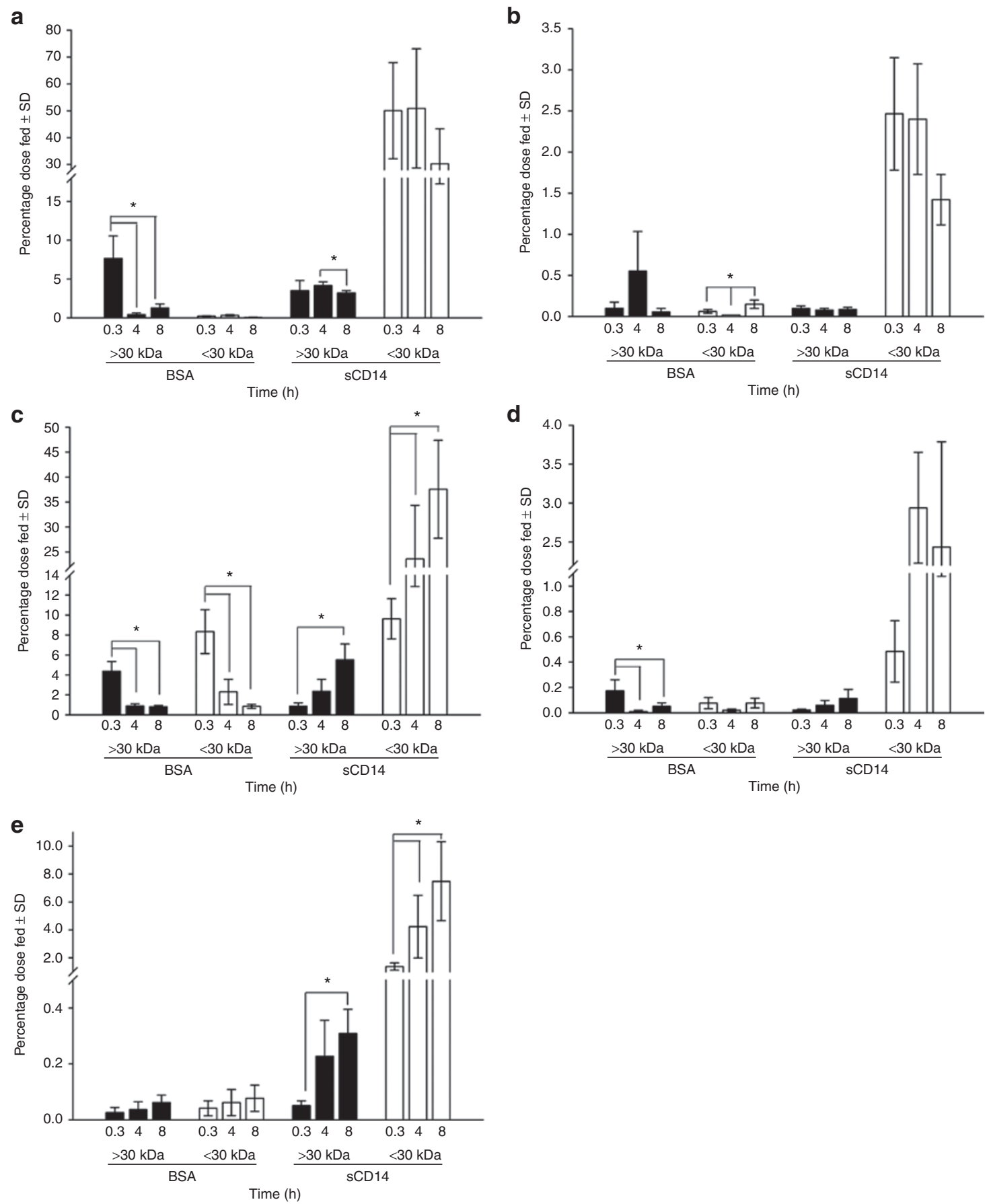

Figure 1. Biodistribution of intact ( $>30 \mathrm{kDa}$, black) and degraded $\left(<30 \mathrm{kDa}\right.$, white) $\left[{ }^{14} \mathrm{C}\right]$-sCD14 and a digestible control protein, $\left[{ }^{14} \mathrm{C}\right]-$ bovine serum albumin (BSA), post-ingestion in 10-d-old rat pups. (a) Stomach; (b) duodenum; (c) jejunum; (d) ileum; and (e) large intestine. Rat pups were gavage fed $25 \mu \mathrm{g}$ of $\left[{ }^{14} \mathrm{C}\right]-\mathrm{sCD} 14\left(1.63 \times 10^{5} \mathrm{dpm} / \mu \mathrm{g}\right)$ or $\left[{ }^{14} \mathrm{C}\right]-\mathrm{BSA}\left(3.44 \times 10^{4} \mathrm{dpm} / \mu \mathrm{g}\right)$. Post-sacrifice $(0.3,4$, or $8 \mathrm{~h})$, proteins were extracted from organs, size separated using a $30-\mathrm{kDa}$ cutoff spin column, and quantified using liquid scintillation counting. Data are presented as mean $\pm \mathrm{SD}$, and $n=3$ for each time point. ${ }^{*} P<0.05$, using a Student's t-test. 


\section{Articles | Ward et al.}

significantly differ from the amount at $0.3 \mathrm{~h}$ post-ingestion (3.5 $\pm 1.3 \%, P=0.838$; Figure 1a). The amount of degraded $\left[{ }^{14} \mathrm{C}\right]-\mathrm{CD} 14$ at $0.3 \mathrm{~h}$ post-ingestion $(50.0 \pm 17.9 \%)$ also did not significantly decrease over the duration of the experiment $(30.3 \pm 13.0 \%$ at $8 \mathrm{~h}, P=0.423)$. This differs from the profile of the digestible control protein, bovine serum albumin (BSA). In the stomach, $7.7 \pm 2.9 \%$ of the $\left[{ }^{14} \mathrm{C}\right]$-BSA dose fed was present intact at $0.3 \mathrm{~h}$, which significantly decreased to $1.3 \pm 0.5 \%$ by $8 \mathrm{~h}$ post-ingestion $(P=0.027$; Figure 1a). The stomach also contained no more than $0.3 \pm 0.1 \%$ of the dose fed of degraded $\left[{ }^{14} \mathrm{C}\right]$-BSA at all time points.

In the duodenum, no more than $2.5 \pm 0.7 \%$ of the $\left[{ }^{14} \mathrm{C}\right]-\mathrm{CD} 14$ dose fed, degraded or intact, was observed at any time point, probably due to the small size of the tissue (Figure 1b). A similar trend was observed for ingested $\left[{ }^{14} \mathrm{C}\right]$-BSA, with no more than $0.5 \pm 0.5 \%$ present in the duodenum, degraded or intact, at any time point (Figure 1b). In the jejunum, however, the amount of intact $\left[{ }^{14} \mathrm{C}\right]-\mathrm{CD} 14$ increased from $0.9 \pm 0.3 \%$ of the dose fed at $0.3 \mathrm{~h}$ to $5.5 \pm 1.6 \%$ of the dose fed at $8 \mathrm{~h}(P=0.045$; Figure 1c). Similarly, the amount of degraded $\left[{ }^{14} \mathrm{C}\right]-\mathrm{CD} 14$ in the jejunum increased from $9.6 \pm 2.0 \%$ at $0.3 \mathrm{~h}$ to $37.5 \pm 9.8 \%$ of the dose fed at $8 \mathrm{~h}$ post-ingestion $(P=0.049)$. The control protein, BSA, showed an opposite trend (Figure 1c). In the jejunum, the amount at $0.3 \mathrm{~h}$ for both intact and degraded BSA (4.4 \pm 1.0 and $8.3 \pm 2.2 \%$, respectively) significantly decreased by $8 \mathrm{~h}(0.8 \pm 0.1 \%(P=0.024)$ and $0.8 \pm 0.2 \%(P=0.027)$, respectively).

Similar to the jejunum, the ileum and the large intestine demonstrated an increase in both intact and degraded $\left[{ }^{14} \mathrm{C}\right]-$ $\mathrm{CD} 14$ from 0.3 to $8 \mathrm{~h}$ post-ingestion. For example, in the large intestine, the $0.05 \pm 0.01 \%$ of the dose fed of intact $\left[{ }^{14} \mathrm{C}\right]$-CD14 significantly increased to $0.3 \pm 0.1 \%$ of the dose fed at $8 \mathrm{~h}$ post-ingestion $(P=0.042$; Figure 1e). The amount of intact BSA, however, decreased in the ileum over time $(0.2 \pm 0.09$ to $0.05 \pm 0.03 \%$ of the dose fed, from 0.3 to $8 \mathrm{~h}, P=0.045)$, and the amount of BSA in the large intestine showed no significant change across time points (Figure 1e).

\section{Ingested sCD14 Is Transferred to the Blood}

Intact $(48 \mathrm{kDa})$ and degraded $\left[{ }^{125} \mathrm{I}\right]-\mathrm{sCD} 14(30$ and $25 \mathrm{kDa})$ were observed in the stomach for up to $8 \mathrm{~h}$ (Figure 2a). By exaggerating the image contrast, intact $\left.{ }^{125} \mathrm{I}\right]-\mathrm{sCD} 14$ was also observed in the jejunum for up to $8 \mathrm{~h}$ post-gavage (see Supplementary Figure S1 online). No $\left.{ }^{125} \mathrm{I}\right]-\mathrm{sCD} 14$ was detected in the duodenum or ileum, probably due to the small size of tissue and relative protein content (see Supplementary Figure S2 online). Most interestingly, intact [ $\left.{ }^{125} \mathrm{I}\right]-\mathrm{sCD} 14(48 \mathrm{kDa})$ was detected in the blood at $4 \mathrm{~h}$ postingestion and persisted up to $8 \mathrm{~h}$ post-ingestion (Figure 2a). In comparison, both intact $(66 \mathrm{kDa})$ and degraded [125] $]$-BSA $(50,40$, and $30 \mathrm{kDa})$ were observed in the stomach for up to $8 \mathrm{~h}$ (Figure $2 \mathrm{~b}$ ). [ $\left.{ }^{125} \mathrm{I}\right]$-BSA was observed in both intact and in multiple degraded forms $(50,40$, and $30 \mathrm{kDa})$ in the duodenum, jejunum, and ileum samples. Neither intact nor degraded $\left[{ }^{125} \mathrm{I}\right]$-BSA was detected in the blood at any of the sampling times (Figure 2b).
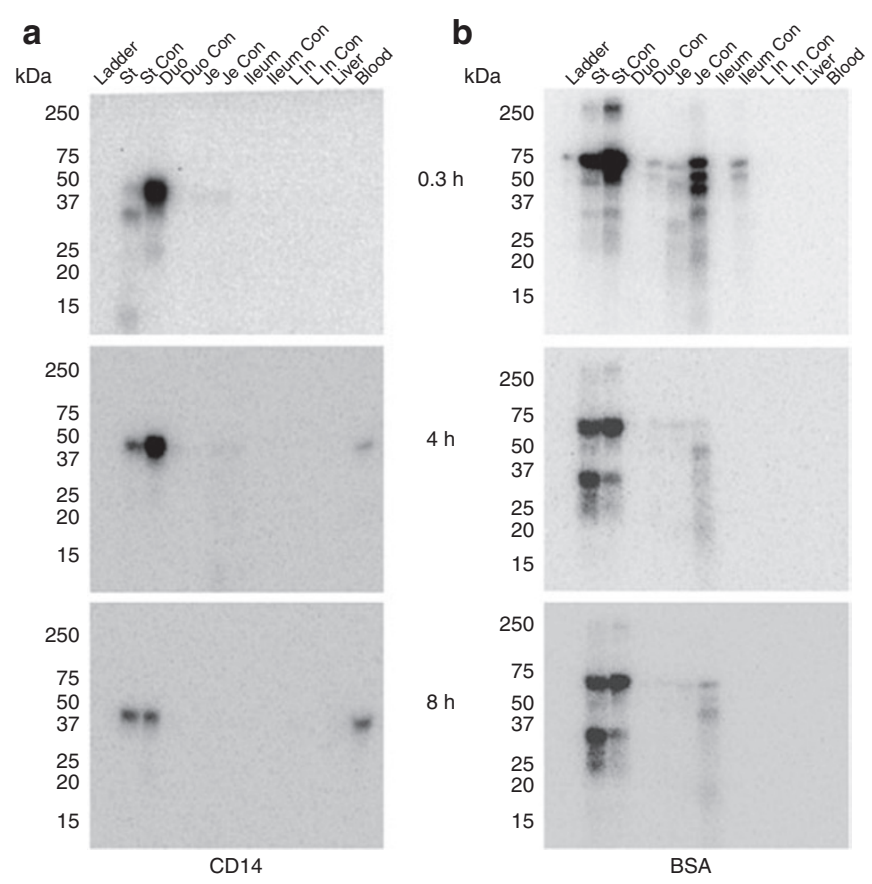

Figure 2. Biodistribution of (a) [125]]-sCD14 and (b) a digestible control protein, [125I]-bovine serum albumin (BSA), post-ingestion in 10-d-old rat pups. Rat pups were gavage fed $25 \mu \mathrm{g}$ of $\left.\left[{ }^{125}\right]\right]-\mathrm{sCD} 14\left(12.16 \times 10^{6} \mathrm{dpm} / \mu \mathrm{g}\right)$ or [ $\left.{ }^{125} \mathrm{I}\right]-\mathrm{BSA}\left(13.7 \times 10^{6} \mathrm{dpm} / \mu \mathrm{g}\right)$. Post-sacrifice $(0.3,4$, or $8 \mathrm{~h})$, proteins were extracted from harvested organs, size separated by sodium dodecyl sulfate-polyacrylamide gel electrophoresis, and phosphor imaged. Stomach (St) and contents (St Con), duodenum (Duo) and contents (Duo Con), jejunum (Je) and contents (Je Con), ileum and contents (lleum Con), large intestine ( $\mathrm{L} \ln )$ and contents ( $\mathrm{L}$ In Con), liver, and blood are shown. Figure is representative of $n=3$.

In a separate experiment, intact $\left[{ }^{125} \mathrm{I}\right]-\mathrm{sCD} 14$ was detected in the blood as early as $0.3 \mathrm{~h}$ post-gavage $(0.5 \pm 0.4 \%$ of the dose fed), which significantly increased to $2.5 \pm 1.2 \%$ of the dose fed by $1 \mathrm{~h}$ post-gavage $(P=0.021$; Figure $3 \mathrm{a})$. The percentage of intact [ $\left.{ }^{125} \mathrm{I}\right]$-sCD14 in the blood did not significantly change after $1 \mathrm{~h}(3.4 \pm 2.2 \%$ of the dose fed at $8 \mathrm{~h}$, Figure 3$)$. Degraded $\left[{ }^{125} \mathrm{I}\right]-\mathrm{sCD} 14$ was also observed in the blood by $0.3 \mathrm{~h}$ post-ingestion, at a concentration of $1.08 \pm 0.5 \%$ of the dose fed. The concentration of degraded $\left[{ }^{125} \mathrm{I}\right]-\mathrm{sCD} 14$ in the blood at $0.3 \mathrm{~h}$ significantly increased at $4 \mathrm{~h}$ post-ingestion $(P$ $=0.024)$, at which time it reached $4.9 \pm 2.0 \%$ of the dose fed (Figure 3b).

Using sodium dodecyl sulfate-polyacrylamide gel electrophoresis (SDS-PAGE) and phosphor imaging, the circulating [ $\left.{ }^{125} \mathrm{I}\right]-\mathrm{sCD} 14$ was confirmed to be fully intact $(48 \mathrm{kDa}$; Figure 4a). Degraded sCD14 was not detected by these methods, probably due to its small size $(<10 \mathrm{kDa})$. This was confirmed by silver staining the SDS-PAGE gels of the $>30$ or $<30-\mathrm{kDa}$ size-fractionated samples, where no protein was observed in the $<30-\mathrm{kDa}$ fraction (Figure $4 \mathrm{~b}$ ).

\section{Rat Milk Contains sCD14}

Because the pups were ingesting rat milk from their mother pre- and post-gavage, any unlabeled rat sCD14 within the milk 

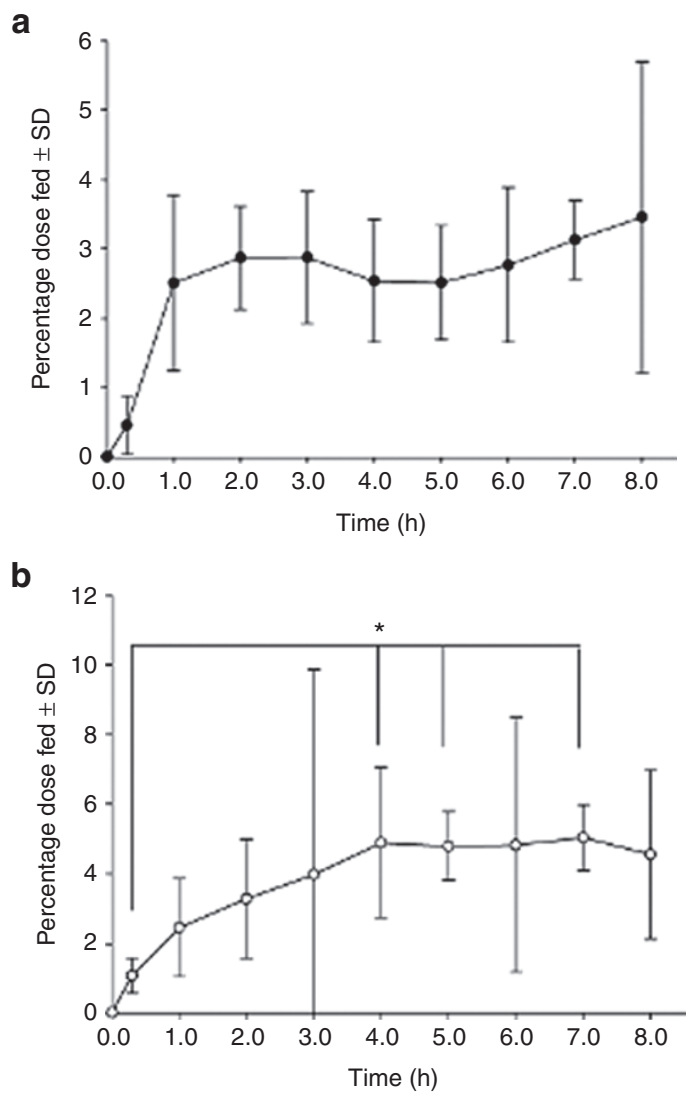

Figure 3. Uptake of (a) intact ( $>30 \mathrm{kDa})$ and (b) degraded $(<30 \mathrm{kDa})$ [125]]-sCD14 into the blood of 10-d-old rat pups. Data are presented as mean $\pm S D$, and $n=4$. (a) Percentage dose fed of sCD14 $>30 \mathrm{kDa}$ at $0.3 \mathrm{~h}$ was significantly less than that at all subsequent time points $\left({ }^{*} P<0.05\right)$. (b) Percentage dose fed of sCD $14<30 \mathrm{kDa}$ at $0.3 \mathrm{~h}$ was significantly less than that at 4,5 , and $7 \mathrm{~h}\left({ }^{*} P<0.05\right.$, Student's $t$-test).

may have hindered uptake of labeled CD14 across the GI tract. A western blot using milk clots from pups fed only phosphatebuffered saline (PBS) showed the presence of sCD14 in rat milk (Figure 5).

\section{DISCUSSION}

The bioactive components of human milk that promote development and provide protection to the infant, including the bacterial sensor sCD14, must be proteolytically resistant to digestion or must form complexes with other proteins to avoid degradation and retain functionality in the infant's GI tract or circulatory system. Secretory IgA and lactoferrin are well-known examples of bioactive proteins that survive passage through the infant's digestive system $(10,16)$. Similarly, in this study, we show that sCD14 was able to evade digestion in the GI tract because $3.2 \pm 0.3 \%$ of ingested $\left[{ }^{14} \mathrm{C}\right]$-CD14 remained undigested in the stomach for up to $8 \mathrm{~h}$. In comparison, the digestible control, BSA, decreased from $7.7 \pm 2.9 \%$ at $0.3 \mathrm{~h}$ to $1.3 \pm 0.5 \%$ of the dose fed at $8 \mathrm{~h}$ post-ingestion (Figure 1a). Soluble CD14 was also able to enter and persist in the small intestine because $5.5 \pm 1.6 \%$ of the dose fed of sCD14 was observed intact in the jejunum at $8 \mathrm{~h}$ post-ingestion (Figure 1c). This persistence may, in part, be due to the

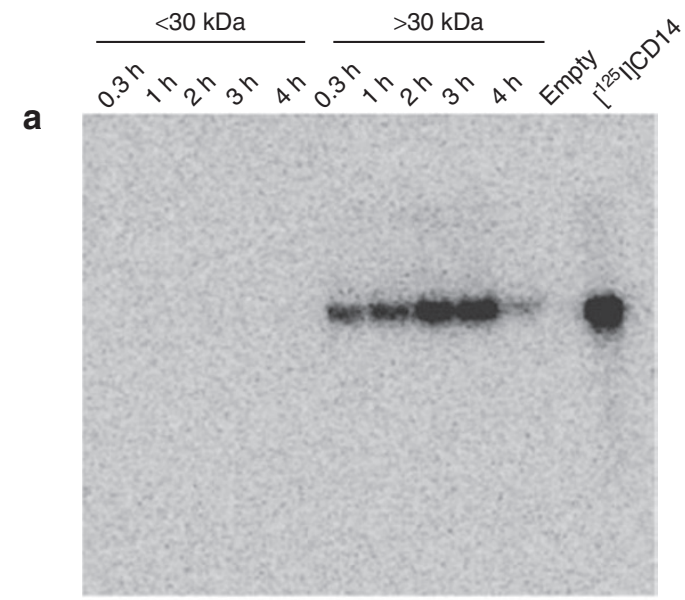

b

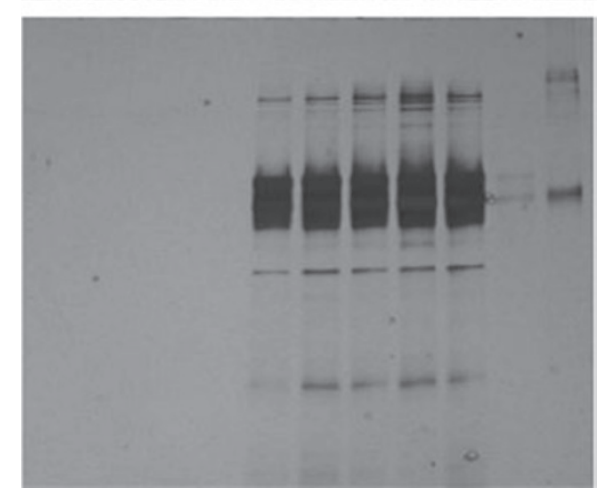

Figure 4. Intactness of ingested [ $\left.{ }^{125} \mathrm{I}\right]-\mathrm{sCD} 14$ in the blood of 10-d-old rat pups after size separation (< or $>30 \mathrm{kDa}$ ) visualized by (a) phosphor imaging and (b) silver staining of SDS-PAGE gels. Intact and non-ingested $\left[{ }^{125} \mathrm{I}\right]-\mathrm{sCD} 14$ was used as a positive control. Figure is representative of $n=4$.

interaction of sCD14 with other milk proteins. For example, we previously showed $\alpha$-lactalbumin to interact with sCD14 in milk and protect it from digestion in vitro (11). Rat milk, which was ingested pre- and post-gavage by the pups, contains $\alpha$-lactalbumin at a concentration of $1.5 \mathrm{~g} / \mathrm{l}$ at $8 \mathrm{~d}$ post parturition, which increases to $3 \mathrm{~g} / \mathrm{l}$ at $15 \mathrm{~d}$ post parturition (17). In vivo, $\alpha$-lactalbumin in rat milk probably confers the same proteolytic protection of $\mathrm{SCD} 14$ observed in vitro.

The high percentage of degraded sCD14 observed in all organs using liquid scintillation counting (Figure 1, white bars) was not observed by SDS-PAGE and phosphor imaging (Figure 2a). This is probably due to the small size of the peptides produced during digestion $(<10 \mathrm{kDa})$, which would migrate off the gel, limiting detection. Previous in vitro work showed human milk sCD14 to be partly resistant to pepsin digestion, which was confirmed herein through the observation of intact sCD14 in the stomach for up to $8 \mathrm{~h}$ post-ingestion (Figure 2a; (10)). Additionally, in vitro pepsin and pancreatin digestion-simulating the small intestine-showed human milk sCD14 to be proteolytically sensitive, and the digestion produced fragments of $\sim 20 \mathrm{kDa}$ (10). In this report, $\left[{ }^{14} \mathrm{C}\right]$-sCD14 of $<30 \mathrm{kDa}$ was detected in the small intestine at all time points (Figure 1b-d), but these fragments were not detected using phosphor imaging (Figure 2). This may be due 


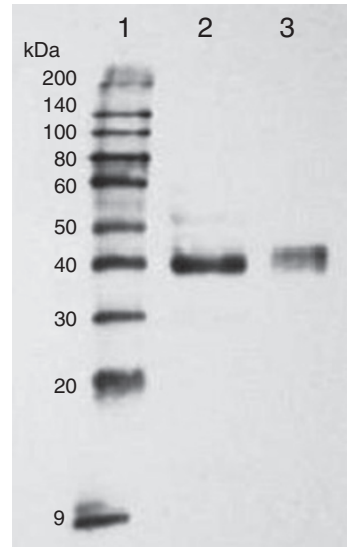

Figure 5. The presence of rat $\mathrm{s} C D 14$ in rat milk, at $10 \mathrm{~d}$ postpartum, as detected by immunoblotting. Lanes: 1 , molecular weight marker; 2 , rat milk; 3 , human recombinant SCD14 (100 ng, positive control).

to the location of the radiolabel along the peptide chain, which may have prevented detection of some fragments depending on how the protein was digested.

Whether intact or degraded, ingested sCD14 may be acting as an important regulator of development in the infant GI tract. Intact sCD14 in the GI tract may aid in dampening the immune response to the influx of colonizing bacteria as the child develops just as SCD14 is able to neutralize bacterial LPS in the blood $(4,18)$. Similarly, degraded sCD14 may provide protection to the infant because sCD14 peptides as small as 20 amino acids (residues $81-100$ especially) have been shown to contain effective LPS-neutralizing capabilities (19). Furthermore, a fragment of CD14 (residues 139-160) has been shown to protect human lymphocytes from gliotoxin-induced death, and $\mathrm{sCD} 14$ has been shown to be a survival factor for leukemic cells $(20,21)$. If sCD14 behaves similarly along the GI tract of infants, it may be promoting gut closure and intestinal epithelial cell homeostasis. In support of this, it has been shown that digested infant formulas, which notably lack $\mathrm{sCD} 14$, increase death of intestinal cells, whereas digested human milk preserves their function (22).

Strikingly, sCD14 was detected intact in the blood at $4 \mathrm{~h}$ post-gavage, where it remained for up to $8 \mathrm{~h}$ (Figure 2a). This finding was confirmed by a second experiment in which the blood of gavage-fed pups was sampled each hour following sCD14 ingestion (Figures 3a and 4a). We found that $3 \%$ of the ingested sCD14 was absorbed intact into the blood, which did not significantly change up to $8 \mathrm{~h}$ post-ingestion (Figure 3a). When extrapolated, this amount may represent up to $30 \%$ of a newborn's circulating sCD14. As more studies describing the milk constituents that are able to cross the tight infant epithelial barrier are published, the notion of "you are what you eat" gains validity. The transfer of beneficial immune components, such as the sCD14 reported here, immunoglobulins, and noninherited maternal antigens, can positively affect the infant's health by conferring additional immunity $(23,24)$. For example, once ingested, noninherited maternal antigens present in the mother's milk convey tolerance to the infant during bone marrow transplantation later in life (24). This type of donated protection via milk into the infant's blood is probably conserved across other immune proteins, such as sCD14.

Whole-protein uptake of milk components has been well described for immunoglobulins and lactoferrin, which are receptor mediated and conserved across species, including humans and rodents $(12,25)$. One potential route of $\mathrm{sCD} 14$ uptake may involve the bacterial recognition receptor TLR4, which is present on multiple gut-associated cell types, including intestinal epithelial cells of adults and newborns (26). TLR4 interacts with both mCD14 and sCD14 to signal the presence of bacteria and alert the immune system. In vitro studies have shown that TLR4 internalization during LPS exposure is CD14 dependent in B cells, and translocation of LPS and whole bacteria by intestinal epithelial cells has been demonstrated in vitro and in vivo $(27,28)$. This internalization of LPS and whole bacteria may represent a potential mechanism for sCD14 uptake in vivo along the GI tract. Soluble CD14 may "piggyback" on luminal LPS while the latter are being translocated. If the uptake of sCD14 is specific and receptor mediated, the proportion $(3.4 \pm 2.2 \%)$ of the intact [ $\left.{ }^{125} \mathrm{I}\right]-\mathrm{sCD} 14$ fed that is translocated to the blood at $8 \mathrm{~h}$ may be an underrepresentation of the total amount of sCD14 absorbed in the GI tract (Figure 3a). Because rat milk contains endogenous rat sCD14 (Figure 5), unlabeled endogenous protein may be competing for the uptake mechanisms used by radiolabeled sCD14, thereby hindering uptake of the labeled protein. Consequently, further experiments to better quantify the total amount of sCD14 translocated to the blood are warranted.

In the blood, the classic role of circulating sCD14 is to attenuate bacteria-induced immune responses by sequestering bacterial components, including LPS, from immune cells and protecting against exaggerated immune responses such as septic shock (4). The exact role of ingested sCD14 in the infant is yet to be determined, but the molecule's newly found associations with inflammation-related diseases suggest that its transfer from mother to infant holds significance. For example, there are numerous situations where removing both mCD14 and $\mathrm{sCD} 14$ expression results in attenuation of inflammationrelated disease phenotypes. In obesity, there is a chronic lowgrade state of inflammation, which is affected by the presence of CD14. When the CD14 coding region was removed from the genome, mice still possessed the ability to become obese, but they gained less fat compared with wild-type mice and suffered from less obesity-related phenotypes, such as hypertension (6). Another closely related example is the effect of CD14 on insulin resistance. Specifically, when wild-type mice were given a bone marrow transplant with CD14-null cells, they no longer became glucose intolerant or insulin resistant when fed a high-fat diet (7). Therefore, sCD14 levels may affect inflammatory responses in the infant.

In the context of LPS response, elevated levels of sCD14 were able to attenuate exaggerated immune responses in mice in otherwise-normal physiological contexts (18). Perhaps the 
presence of additional sCD14, obtained from the mother's milk, provides similar protection for the infant both during the LPS response and in other systems. For example, delivering additional recombinant sCD14 via injection to adult wild-type mice was able to increase glucose tolerance and increased the action of insulin in the same manner as a total CD14 knockout (7). Furthermore, the ability of additional sCD14 to ameliorate negative inflammatory symptoms was also seen in allergy development. It has been shown that children with allergies often have decreased levels of circulating sCD14 and that exogenous $\mathrm{sCD} 14$ was able to suppress allergen-induced $\mathrm{T}$ helper cell 2 differentiation in vitro $(8,29)$. The link between the level of sCD14 in mother's milk and the development of atopy and eczema in the infant, however, remains controversial (30-32).

Therefore, the significance of the transfer of sCD14 from human milk into the circulation of the infant should not be underestimated. As new roles of $\mathrm{sCD} 14$ in disease pathogenesis are uncovered, the protein's impact on infant development may become clearer. Current work includes the use of CD14null mice to determine the unhindered quantity of ingested sCD14 transferred to the infant's blood and the functionality of ingested sCD14 in vivo by testing its capability to detect LPS. Future studies to determine the benefit of sCD14 ingestion in the infant with regard to other systems, such as GI colonization, obesity, diabetes, and allergy, are imperative.

\section{METHODS}

\section{Radiolabeling of Proteins}

Human recombinant SCD14 (R\&D Systems, Minneapolis, MN) and BSA (Sigma-Aldrich, Oakville, Ontario, Canada) were labeled with $\left[{ }^{14} \mathrm{C}\right]$-methyl iodide using $52.9 \mathrm{mCi} / \mathrm{mmol}(\mathrm{sCD} 14)$ or $10 \mathrm{mCi} / \mathrm{mmol}$ (BSA; Perkin Elmer, Waltham, MA; and Sigma-Aldrich). Proteins (100 $\mu \mathrm{g}$ of sCD14 or $500 \mu \mathrm{g}$ of BSA) were lyophilized and labeled using our previously established protocol (33).

Separately, sCD14 and BSA were labeled with [ $\left.{ }^{125} \mathrm{I}\right]-\mathrm{NaI}$ (MP Biomedical, Solon, $\mathrm{OH}$ ) using Iodination Beads (Thermo Scientific, Rockford, IL) following the manufacturer's protocol with $100 \mu \mathrm{g}$ of protein and $1 \mathrm{mCi}$ of $\left.{ }^{[25} \mathrm{I}\right]-\mathrm{NaI}$ in a total volume of $1.1 \mathrm{ml}$ PBS. Proteins were recovered by centrifugation at $1,000 \mathrm{~g}$ for $2 \mathrm{~min}$ using a $2 \mathrm{ml}$ Zeba Desalt spin column (Thermo Scientific). The resultant specific radioactivity levels were as follows: $\left[{ }^{14} \mathrm{C}\right]-\mathrm{SCD} 14,1.63 \times 10^{5}$ disintegrations per minute $(\mathrm{dpm}) / \mu \mathrm{g} ;\left[{ }^{14} \mathrm{C}\right]-\mathrm{BSA}, 3.44 \times 10^{4} \mathrm{dpm} / \mu \mathrm{g}$; $\left[{ }^{125} \mathrm{I}\right]$-sCD $14,12.16 \times 10^{6} \mathrm{dpm} / \mu \mathrm{g}$; and $\left[{ }^{125} \mathrm{I}\right]-\mathrm{BSA}, 13.7 \times 10^{6} \mathrm{dpm} / \mu \mathrm{g}$. Radiolabeled proteins were stored at $-70^{\circ} \mathrm{C}$.

\section{Feeding Studies and Protein Isolation}

Feeding studies were conducted in accordance with the University of Ottawa's Animal Care and Veterinary Service under approval permit ID number "BMI 77" and approved by the University of Ottawa's Animal Care Committee. Sprague Dawley rat pups aged $10 \mathrm{~d}$ were used as a model for preweaning infants as at this age, the animals only ingest their mothers' milk. In total, 26 pups (derived from three litters of 13 pups each) weighing between 11 and $26 \mathrm{~g}$ were fasted for $2 \mathrm{~h}$ at $37^{\circ} \mathrm{C}$ to partially empty the stomach and accommodate for the gavage protein solution (34). Pups were gavage fed $25 \mu \mathrm{g}$ of $\left[{ }^{14} \mathrm{C}\right]-\mathrm{sCD} 14$, $\left[{ }^{14} \mathrm{C}\right]-\mathrm{BSA},\left[{ }^{125} \mathrm{I}\right]-\mathrm{sCD} 14$, or $\left[{ }^{125} \mathrm{I}\right]-\mathrm{BSA}$ in $250 \mu \mathrm{l}$ of PBS using our previous technique (34). As a control, one pup per experiment was fed PBS alone (data not shown). BSA was chosen as a digestible control because it is known to be easily degraded and absorbed in the GI tract (35). Animals were anesthetized with isoflurane at $0.3,4$, and $8 \mathrm{~h}$ postgavage and sacrificed by cardiac puncture. Organs were harvested, flash frozen in liquid nitrogen, and stored at $-70^{\circ} \mathrm{C}$. The GI tract was separated into the duodenum, jejunum, ileum, and large intestine by length $(7,80,2$, and $11 \%$, respectively; (36)).
To determine the amount of sCD14 transferred to the blood, five 10 -d-old Sprague Dawley pups were fasted as described above and gavage fed $25 \mu \mathrm{g}$ of $\left[{ }^{125} \mathrm{I}\right]$-sCD14 or PBS alone (data not shown) and returned to their mother. Blood samples $(10 \mu \mathrm{l})$ were collected from the hind leg by needle prick for up to $8 \mathrm{~h}$ post-gavage and stored at $-70{ }^{\circ} \mathrm{C}$.

\section{Quantifying Intact and Degraded Proteins}

Organs and luminal contents were weighed and homogenized on ice in $150 \mu \mathrm{l}$ buffer (containing $50 \mathrm{mmol} / \mathrm{l}$ tris(hydroxymethyl)aminomethane ( $\mathrm{pH} 7.4), 2 \mathrm{mmol} / \mathrm{l}$ ethylenediaminetetraacetate, 150 $\mathrm{mmol} / 1 \mathrm{NaCl}, 0.5 \mathrm{mmol} / \mathrm{l}$ dithiothreitol, and protease inhibitor cocktail; Sigma-Aldrich) using a micropestle (Eppendorf, Westbury, NY). Samples were sonicated on ice three times using a 30-s on/off cycle at $5 \mathrm{~W}$, and cell debris was removed by centrifugation. Samples were prefiltered using a $0.22-\mu \mathrm{m}$ spin filter (Amicon, Millipore, Bedford, MA), followed by separation through a 30,000 Da molecular weight cutoff spin filter (Amicon). Flow-through solutions $(<30 \mathrm{kDa})$ and retentates $(>30 \mathrm{kDa})$ were added to $5 \mathrm{ml}$ of liquid scintillation cocktail (ScintiSafe-Econo1, Fisher Scientific, Ottawa, Ontario, Canada) and radioactivity levels were quantified using a Tri-Carb liquid scintillation counter (Perkin Elmer).

\section{Determining Protein Intactness}

Isolated proteins were subjected to size separation by SDS-PAGE using AnyKD SDS-polyacrylamide gradient gels (Bio-Rad, Mississauga, Ontario, Canada) and electrophoresis. Gels were silver stained, exposed to a storage phosphor screen (GE Healthcare, Piscataway, NJ), and imaged using a Typhoon Trio Imager (GE Healthcare).

\section{Detecting CD14 in Rat Milk}

From three pups fed PBS alone, stomach contents were resuspended in PBS and pooled. Proteins, including $100 \mathrm{ng}$ of human recombinant CD14 (R\&D Systems) as a positive control and a biotinylated molecular weight marker (7727, Cell Signaling Technology, Danvers, MA), were size separated using SDS-PAGE and transferred to nitrocellulose membrane. A mouse anti-human CD14 antibody (cross-reactive to rat CD14, MAB 3831, R\&D Systems), a goat anti-mouse IgG horseradish peroxidase-linked antibody (HAF007, R\&D Systems), and a goat anti-biotin horseradish peroxidase-linked antibody to recognize the molecular weight markers (7727, Cell Signaling Technology) were used in a western blot of the milk proteins. Proteins were visualized using exposure to enhanced chemiluminescent substrate (GE Healthcare).

\section{Data Analysis}

Percentage dose was calculated using the formula $[(\mathrm{dpm} / \mathrm{g}$ organ $) \times$ (total organ weight)]/dpm dose fed of sCD14. Total organ weight of blood was calculated using the approximation that blood represents $7 \%$ of the body weight. Data were analyzed by two-tailed paired or unpaired $t$-tests (Sigma Plot 12.1, Systat, San Jose, CA). An alpha level of $<0.05$ was considered significant.

\section{SUPPLEMENTARY MATERIAL}

Supplementary material is linked to the online version of the paper at http:// www.nature.com/pr

\section{ACKNOWLEDGMENTS}

We thank V.T. Pham and H. Kaplan from Anhydrovac for technical assistance, C.M. Yanofsky and D.R. Bickel for help with statistical analysis, and the staff of the Animal Care and Veterinary Services for their excellent assistance with animals.

\section{STATEMENT OF FINANCIAL SUPPORT}

This research was supported by the Canadian Institutes of Health Research, Nutrition, Metabolism and Diabetes Committee (ClHR, grant 82816).

Disclosure: The authors declare no competing financial interests.

\section{ADDITIONAL AUTHOR INFORMATION}

T.L.W., W.J.S., and I.A. designed the research. T.L.W., W.J.S., and L.D.R.D. conducted the research. T.L.W. analyzed the data and wrote the manuscript, which was edited by I.A., J.H., and D.R.M. All authors read and approved the final manuscript. 


\section{REFERENCES}

1. Labeta MO, Vidal K, Nores JE, et al. Innate recognition of bacteria in human milk is mediated by a milk-derived highly expressed pattern recognition receptor, soluble CD14. J Exp Med 2000;191:1807-12.

2. Vidal K, Labéta MO, Schiffrin EJ, Donnet-Hughes A. Soluble CD14 in human breast milk and its role in innate immune responses. Acta Odontol Scand 2001;59:330-4.

3. Frey EA, Miller DS, Jahr TG, et al. Soluble CD14 participates in the response of cells to lipopolysaccharide. J Exp Med 1992;176:1665-71.

4. Kitchens RL, Thompson PA, Viriyakosol S, O'Keefe GE, Munford RS. Plasma CD14 decreases monocyte responses to LPS by transferring cellbound LPS to plasma lipoproteins. J Clin Invest 2001;108:485-93.

5. Collado MC, Laitinen K, Salminen S, Isolauri E. Maternal weight and excessive weight gain during pregnancy modify the immunomodulatory potential of breast milk. Pediatr Res 2012;72:77-85.

6. Roncon-Albuquerque R Jr, Moreira-Rodrigues M, Faria B, et al. Attenuation of the cardiovascular and metabolic complications of obesity in CD14 knockout mice. Life Sci 2008;83:502-10.

7. Fernández-Real JM, Pérez del Pulgar S, Luche E, et al. CD14 modulates inflammation-driven insulin resistance. Diabetes 2011;60:2179-86.

8. Lundell AC, Adlerberth I, Lindberg E, et al. Increased levels of circulating soluble CD14 but not CD83 in infants are associated with early intestinal colonization with Staphylococcus aureus. Clin Exp Allergy 2007;37:62-71.

9. Chatterton DE, Nguyen DN, Bering SB, Sangild PT. Anti-inflammatory mechanisms of bioactive milk proteins in the intestine of newborns. Int J Biochem Cell Biol 2013;45:1730-47.

10. Blais DR, Harrold J, Altosaar I. Killing the messenger in the nick of time: persistence of breast milk sCD14 in the neonatal gastrointestinal tract. Pediatr Res 2006;59:371-6.

11. Spencer WJ, Binette A, Ward TL, et al. Alpha-lactalbumin in human milk alters the proteolytic degradation of soluble CD14 by forming a complex. Pediatr Res 2010;68:490-3.

12. Ladinsky MS, Huey-Tubman KE, Bjorkman PJ. Electron tomography of late stages of FcRn-mediated antibody transcytosis in neonatal rat small intestine. Mol Biol Cell 2012;23:2537-45.

13. Kuo TT, Baker K, Yoshida M, et al. Neonatal Fc receptor: from immunity to therapeutics. J Clin Immunol 2010;30:777-89.

14. Taylor SN, Basile LA, Ebeling M, Wagner CL. Intestinal permeability in preterm infants by feeding type: mother's milk versus formula. Breastfeed Med 2009;4:11-5.

15. Teichberg S, Isolauri E, Wapnir RA, Roberts B, Lifshitz F. Development of the neonatal rat small intestinal barrier to nonspecific macromolecular absorption: effect of early weaning to artificial diets. Pediatr Res 1990;28:31-7.

16. Goldman AS, Garza C, Schanler RJ, Goldblum RM. Molecular forms of lactoferrin in stool and urine from infants fed human milk. Pediatr Res 1990;27:252-5.

17. Nicholas KR, Hartmann PE, McDonald BL. Alpha-Lactalbumin and lactose concentrations in rat milk during lactation. Biochem J 1981;194:149-54.

18. Jacque B, Stephan K, Smirnova I, Kim B, Gilling D, Poltorak A. Mice expressing high levels of soluble CD14 retain LPS in the circulation and are resistant to LPS-induced lethality. Eur J Immunol 2006;36:3007-16.

19. Voss S, Welte S, Fotin-Mleczek M, et al. A CD14 domain with lipopolysaccharide-binding and -neutralizing activity. Chembiochem 2006;7:275-86.
20. Tartakovsky B, Sredni B, Zigman-Hoffman E, Senyor G, Naparstek E. A peptide of CD14 protects human lymphocytes from gliotoxin-induced apoptosis. Int J Pept Res Ther 2012;18:249-58.

21. Seiffert M, Schulz A, Ohl S, Döhner H, Stilgenbauer S, Lichter P. Soluble CD14 is a novel monocyte-derived survival factor for chronic lymphocytic leukemia cells, which is induced by CLL cells in vitro and present at abnormally high levels in vivo. Blood 2010;116:4223-30.

22. Penn AH, Altshuler AE, Small JW, Taylor SF, Dobkins KR, Schmid-Schönbein GW. Digested formula but not digested fresh human milk causes death of intestinal cells in vitro: implications for necrotizing enterocolitis. Pediatr Res 2012;72:560-7.

23. Weltzin R, Lucia-Jandris P, Michetti P, Fields BN, Kraehenbuhl JP, Neutra MR. Binding and transepithelial transport of immunoglobulins by intestinal M cells: demonstration using monoclonal IgA antibodies against enteric viral proteins. J Cell Biol 1989;108:1673-85.

24. Aoyama K, Koyama M, Matsuoka K, et al. Improved outcome of allogeneic bone marrow transplantation due to breastfeeding-induced tolerance to maternal antigens. Blood 2009;113:1829-33.

25. Lönnerdal B, Jiang $\mathrm{R}, \mathrm{Du} \mathrm{X}$. Bovine lactoferrin can be taken up by the human intestinal lactoferrin receptor and exert bioactivities. J Pediatr Gastroenterol Nutr 2011;53:606-14.

26. Vamadevan AS, Fukata M, Arnold ET, Thomas LS, Hsu D, Abreu MT. Regulation of Toll-like receptor 4-associated MD-2 in intestinal epithelial cells: a comprehensive analysis. Innate Immun 2010;16:93-103.

27. Tanimura N, Saitoh S, Matsumoto F, Akashi-Takamura S, Miyake K. Roles for LPS-dependent interaction and relocation of TLR4 and TRAM in TRIF-signaling. Biochem Biophys Res Commun 2008;368:94-9.

28. Neal MD, Leaphart C, Levy R, et al. Enterocyte TLR4 mediates phagocytosis and translocation of bacteria across the intestinal barrier. J Immunol 2006;176:3070-9.

29. Lundell AC, Andersson K, Josefsson E, Steinkasserer A, Rudin A. Soluble CD14 and CD83 from human neonatal antigen-presenting cells are inducible by commensal bacteria and suppress allergen-induced human neonatal Th2 differentiation. Infect Immun 2007;75:4097-104.

30. Jones CA, Holloway JA, Popplewell EJ, et al. Reduced soluble CD14 levels in amniotic fluid and breast milk are associated with the subsequent development of atopy, eczema, or both. J Allergy Clin Immunol 2002;109:858-66.

31. Savilahti E, Siltanen M, Kajosaari M, Vaarala O, Saarinen KM. IgA antibodies, TGF-beta1 and -beta2, and soluble CD14 in the colostrum and development of atopy by age 4 . Pediatr Res 2005;58:1300-5.

32. Ismail IH, Licciardi PV, Oppedisano F, Boyle RJ, Tang ML. Relationship between breast milk sCD14, TGF- 11 and total $\operatorname{IgA}$ in the first month and development of eczema during infancy. Pediatr Allergy Immunol 2013;24:352-60.

33. Davis LD, Spencer WJ, Pham VT, et al. (14)C radiolabeling of proteins to monitor biodistribution of ingested proteins. Anal Biochem 2011;410:57-61.

34. Davis LD, Spencer WJ, Mack DR, Altosaar I. Maternal separation and gastrointestinal transit time in neonate rats. Lab Anim 2011;45:280-2.

35. Eriksen EK, Holm H, Jensen E, et al. Different digestion of caprine whey proteins by human and porcine gastrointestinal enzymes. Br J Nutr 2010;104:374-81.

36. DeSesso JM, Williams AL, John EM. Contrasting the gastrointestinal tracts of mammals: factors that influence absorption. Annu Rep Med Chem 2008;43:353-71. 